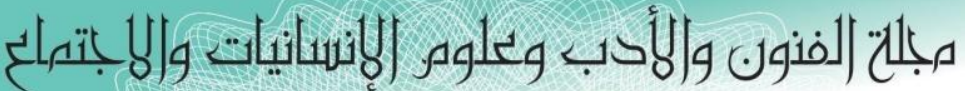

Joumal of Arts, Literature, Humanities and Social Sciences

ISSN online: 2414 - 3383

العدد (44) أكتوبر 2019

ISSN print: 2616 - 3810

Volume (44) October 2019

¿ALLHSS

WWw.jalhss.com

\title{
Translation Technique and its Uses in Learning English as a Foreign Language at Mosul University
}

\author{
Lecturer: Osama Misbah Mahmood Al-Hamdani \\ Department of Translation/ College of Arts/ Mosul University/ Iraq \\ osamaalhamdani618@yahoo.com
}

\begin{abstract}
Translation techniques and procedures have received a great deal of attention by western theorists of translation. However, to the best of our knowledge no work concerning the study of "translation techniques, procedures and their uses in teaching English as a foreign language at Mosul University" was carried out. The present study is to a bridge that gap. It is well-known, that modern language teaching traditionally overuses and misuses translation in the class -room due to failure to understand the principles of teaching. The current paper tackles the use of translation in teaching English as a foreign language at Mosul University. It aims to help students to develop and reinforce their competence and knowledge regarding English Language .Hence, translation is considered as a "pedagogical device". Furthermore, translation lets learners communicate into and from the foreign language. Doing that, learners will recognize the differences and similarities in lexicons, syntactic structures, and semantic elements of both languages Consequently, students will have a clear contrastive view of languages in question. The main finding of this study is that translation can be regarded as a very good device for teaching English as foreign language.
\end{abstract}




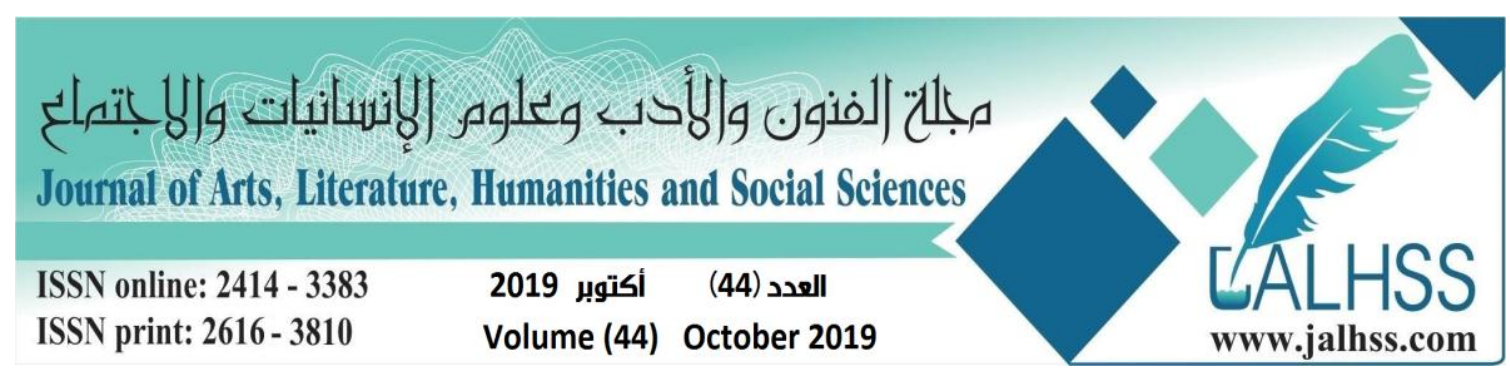

\section{Introduction}

Throughout this study, translation will be presented as a process which begins with the source text, analyzes this text into semantic structure, and then restructures this semantic structure into appropriate receptor language forms in order to create an equivalent receptor language text. This is a very general way of looking at the translation process. Translation is actually much more complicated than such an overview might indicate. In actual practice, the translator moves back and forth from the source text to the receptor text. Sometimes he will be analyzing the source text in order to find the meaning, then restructuring this meaning in the receptor language, and moving back once again to look at the source text or the semantic analysis which he has done. All three are repeatedly looked at as he works. Below, we will discuss the techniques and procedures, which the translator follows as if they were done in a given order. But it must be kept in mind that, in practice, there will be this moving back and forth. At times, even while he is working on the final draft, the translator will go back and re-read things he looked at in his preparation. $\mathrm{He}$ should, as a matter of fact, often refer back to these materials. Furthermore, translation technique for teaching English as a foreign language will be reviewed.

\section{Translation Techniques for Facilitating Teaching}

In this section we are going to talk about translation techniques. Just as there are different types of translation and different methods of translation, there are different techniques of translation as well as different techniques of teaching English Language.

\section{Translation Techniques vs. Translation Methods}

What is the difference between a translation method and a technique? It is very simple: a translation method is applied to the entire text to be translated, while a translation technique may vary within the same text according to each case and depending on the specific verbal elements to be translated. The classical taxonomy of translation procedures dates back to 1958 and is the work of J. P. Vinay and J. Darbelnet. It consists of seven categories:

\subsection{Borrowing}

Borrowing is a translation technique that involves using the same word or expression in original text in the target text. The word or expression borrowed is usually written in italics. This is about reproducing an expression in the original text as it is. In this sense, it is a translation technique that does not actually translate.

Example: The gaucho was wearing a black sombrero and a worn old pair of bombachas (Vinay and Darblent, 1995).

\subsection{Calque}

When a translator uses a calque, he or she is creating or using a neologism in the target language by adopting the structure of the source language. 


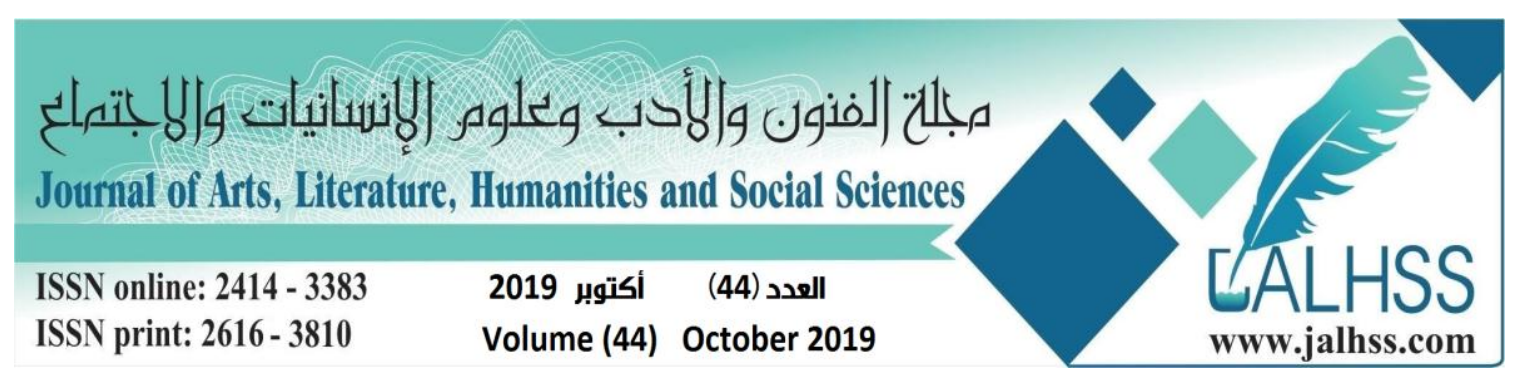

Example: The English word handball is translated into Spanish as balonmano. Or the English term skyscraper is gratte-ciel in French or rascacielos in Spanish (Vinay and Darblent, 1995) .

\subsection{Literal Translation}

Usually this is called a literal translation or metaphrase. This means a word-forword translation, achieving a text in the target language which is as correct as it is idiomatic. According to Vinay and Darbelnet, a literal translation can only be applied with languages which are extremely close in cultural terms. It is acceptable only if the translated text retains the same syntax, the same meaning and the same style as the original text.

Example: Quelle heure est-il? $\Rightarrow$ What time is it? ( Catford, 1965) .

\subsection{Transposition}

Transposition involves moving from one grammatical category to another without altering the meaning of the text. This translation technique introduces a change in grammatical structure.

Example: The President thinks that $\Rightarrow$ Selon le Président (See also Venuti,1995)

\subsection{Modulation}

Modulation is about changing the form of the text by introducing a semantic change or perspective.

Example: Maybe you're right $\Rightarrow$ Tu n'as peut-être pas tort (Vinay and Darblent, 1995) .

\subsection{Equivalence or Reformulation}

This is a translation technique which uses a completely different expression to transmit the same reality. Through this technique, names of institutions, interjections, idioms or proverbs can be translated.

Example: Chat échaudé craint l'eau froide $\Rightarrow$ Once burned, twice shy (Vinay and Darblent, 1995 and also Vinuti, 1995 and 1998).

\subsection{Adaptation}

Adaptation, also called cultural substitution or cultural equivalent, is a cultural element which replaces the original text with one that is better suited to the culture of the target language. This achieves a more familiar and comprehensive text.

Example: baseball $\Rightarrow$ football

Since the sixties, several authors (Michel Ballard, Hélène Chuquet, Michel Paillard, etc.) have established other methods of translation, such as explicitation (introducing specific details in the text of the target language), collocation (using a sequence of words that usually go together in the target language) and compensation (where an allusion or reference does not appear in one part of the text as in the source version, but later in the target text) (Bernardini, 2016). 


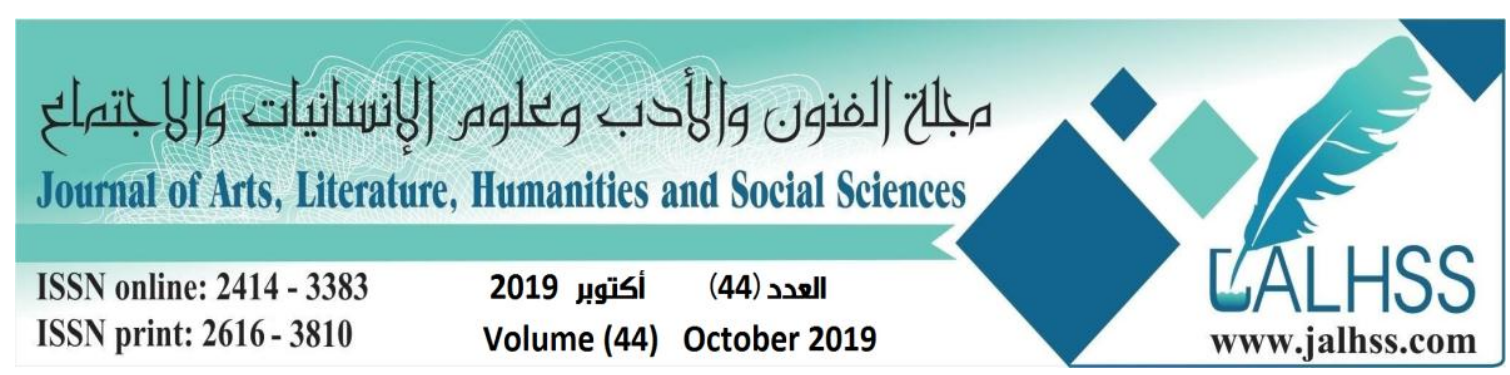

\section{Translation Techniques and Procedures}

Translation techniques and procedures always depend on a variety of contextual factors. They are used for sentences and smaller units of language rather than whole texts. In what follows the fundamental techniques and procedures relevant to the actual performing of the task will be explained in some details.

\subsection{Nida's Translation Procedures}

The fundamental procedures which have been relevant to the actual performing of the task of translation can be divided roughly into two categories: (1) technical procedures, and (2) organizational procedures. Technical procedures concern the processes followed by the translator in converting a source-language text into a receptor-language text; organizational procedures involve the general organization of such work, whether in terms of a single translator or, as is true in many instances, of a committee. (Nida, 1995: 224).

\subsubsection{Technical Procedures}

Technical procedures consist, essentially, of three phases: (1) analysis of the respective languages, source and receptor; (2) careful study of the sourcelanguage text; and (3) determination of the appropriate equivalents. (Nida, 1995: 225).

\subsubsection{Organizational Procedures}

The technical procedures apply to any and all types of translating, but there are different types of procedural problems, owing to the diverse ways in which a translation process may be organized. There are naturally many varieties of such organization, as implied elsewhere in the description of the pioneer, midwife, and split-personality types. Moreover revisions are in some ways a good deal more difficult than original translations, and hence often involve very complex procedures, usually because of vested interests. (Nida, 1995: 225).

On the other hand it is possible to exaggerate the differences between translation and revision. Hence, in the following outline of organizational procedures, an attempt is made to distinguish between the two processes. By implication, certain important distinctions between translating by a single person and by a committee which can be attributed to the fact that revisions are most often done by committees-usually because they involve a larger constituency and more numerous vested interests. Under these conditions there are more persons who must be consulted, or who think they should be consulted.

\subsection{Newmark's Translating Procedures}

This section is going to focus mainly on the procedures of translation that have been proposed by Newmark (1981,1988 and 1991). They are as follows:

(1)Transference: Transference is the process of transferring a SL word to a TL text as a translation procedure. It is the same as Catford's transference, and includes translation, which relates to the conversion of different alphabets: e.g. 


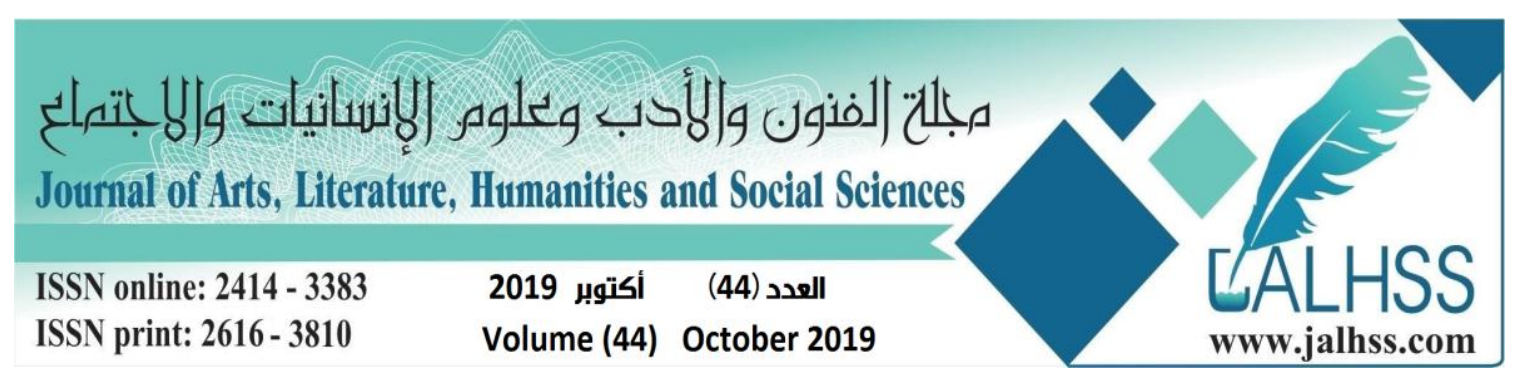

Russian (Cyrillic), Greek, Arabic, Chinese, etc. into English. The word then becomes a "loan word". Some authorities deny that this is a translation procedure, but no other term is appropriate if a translator decides to use an SL word for his text. However, when the translator has to decide whether or not to transfer a word unfamiliar in the target language, which in principle should be a SL cultural word whose referent is peculiar to the SL culture, then he usually complements it with a second translation procedure-the two procedures in harness are referred to as a "couplet". Generally, only cultural "objects" or concepts related to a small group or cult should be transferred; the vogue for transferring so called "national characteristics" should be abandoned. Needless to say, in principle, the names of SL objects, inventions, devices, processes to be imported into the TL community should be creatively, preferably "authoritatively", translated, if they are neologisms, although brand names have to be transferred. It is not the translator's job to assist any SL advertiser's financial, national or personal prestige interests. At the same time, one cannot be rigid or dogmatic. The media, the experts, will be transferring words whether the translators like it or not. Perhaps when the translator's professional status is raised, they will not be transferring so many (Newmark , 1981, 1988 and 1991).

(2)Naturalization: This procedure succeeds transference and adapts the SL word first to the normal pronunciation, then to the normal morphology (wordforms) of the TL, e.g. Edinburgh, humeur. Note, for German, Performanz, attraktiv.

(3)Cultural Equivalent: This is an approximate translation where a SL cultural word is translated by a TL cultural word; thus baccalaureat is translated as (the French) "A" level, or Abitur (Matura) as (the German/Austrian) "A" level; Palais Bourbon as (the French) Westminster. The above are approximate cultural equivalents. Their translation uses are limited, since they are not accurate, but they can be used in general texts, publicity and propaganda, as well as for brief explanation to readers who are ignorant of the relevant SL culture. They have a greater pragmatic impact than culturally neutral terms. Occasionally, they may be purely functionally, hardly descriptively, equivalents, e.g. "baseball", "tea break", café-pause art d'identite, "car licence". Functional cultural equivalents are even more restricted in translation, but they may occasionally be used if the term is of little importance in a popular article or popular fiction. They are important in drama, as they can create an immediate effect. "He met her in the pub'-Ill' a retrouvee dans le café. However, the main purpose of the orocedure is to support or supplement another translation procedure in a couplet (Newmark , 1981, 1988 and 1991).

(4)Functional Equivalent: This common procedure, applied to cultural words, requires the use of a culture-free word, sometimes with a new specific term; it therefore neutralizes or generalizes the SL word; and sometimes adds a particular thus: baccalaureat "French secondary school leaving exam". This procedure, which is a cultural componential analysis, is the most accurate way 


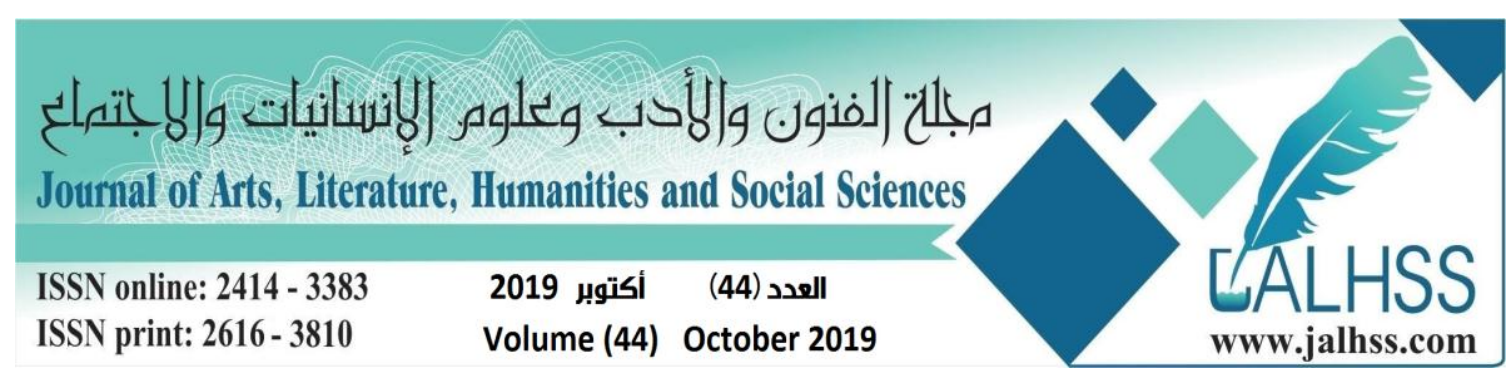

of translating i.e. deculturalising a cultural word. A similar procedure is used when a SL technical word has no TL equivalent. Thus the English term "cot death" translates as mort subite d'un nourrisson, although the components "unexpected" and "without known reason" are here omitted from the French. This procedure occupies the middle, sometimes the universal, area between the SL language or culture and the TL language or culture. If practiced one to one, it is an under-translation. if practiced one to two, it may be an over-translation. for cultural terms, it is often combined with transference: taille, as "a tax on the common people befor the French Revolution, or taille" He refers to the combination of two translation procedures for one unit as a couplet (Newmark, 1981, 1988, 1991 and AL-Sulaimaan , 2016:209).

(5)Descriptive Equivalent: In translation, description sometimes has to be weighed against function. Thus machete, the description is a "Latin American broad, heavy instrument", the function is "cutting or aggression"; description and function are combined in "knife". Samurai is described as "the Japanese aristocracy from the eleventh to the nineteenth century"; its function was "to provide officers and administrators". Description and function are essential elements in explanation and therefore in translation. in translation discussion, function used to be neglected; now it tends to be overplayed.

\section{Vinay and Darbelent's Translation Techniques}

Vinay and Darbelent (1995) also used two types of techniques. They are as follows:

(1)Equivalence, an unfortunately named term implying approximate equivalence, accounting for the same situation in different terms. Judging from Vinay and Darbelnet's (1995) example, they are simply referring to notices, familiar alternatives, phrases and idioms-in other words, different ways of rendering the clichés and standard aspects of language, e.g. "The story so far", Resume des chapitres precedents.

(2)Adaptation: use of a recognized equivalent between two situations. This is a matter of cultural equivalence, such as "Dear Sir" translated as Monsieur; (اليدي (المخلص لك) (Yours ever" as Amities, Both the above illuminate what sometimes happens in the process of translating, but the are not usable procedures. As I see it, there are about fourteen procedures within a certain range of probability which are useful to the translator.

\section{Graedler's Techniques}

Greaedler (2000) puts forth some techniques of translating culture as follows:

(1) Making up a new word.

(2) Explaining the meaning of the SL expression in lieu of translating it.

(3) Preserving the SL term intact. 


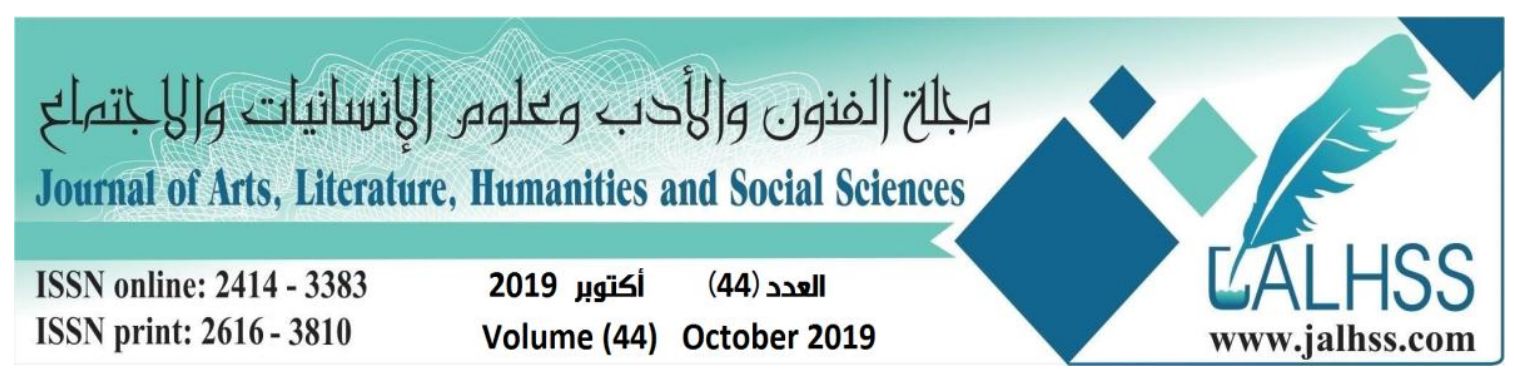

(4) Opting for a word in the TL which seems similar to or has the same "relevance" as the SL term.

\section{Harvey's Translation Techniques}

Defining culture-bound terms as the terms which "refer to concepts, institutions and personnel which are specific to the SL culture" (Harvey,2000): He puts forward the following four major techniques for translating culture-bound terms.

(1)Functional Equivalence: It means using a referent in the TL culture whose function is similar to that of the source language (SL) referent. As Harvey (2000) writes, authors are divided over the merits of this technique: Westtein (1991) describes it as "the ideal method of translation" while Sarcevic (1985) asserts that it is "misleading and should be avoided".

(2)Formal Equivalence: Or "linguistic equivalence" it means "word-for-word translation.

(3)Transcription: Or "borrowing" (i.e. reproducing or, where necessary, transliterating the original term): it stands at the far end of SL-oriented strategies. If the term is formally transparent or is explainedin the context, it may be used alone. In other cases. Particularly where no knowledge of the SL by the reader is presumed, transcription is accompanied by an explanation or a translator's note.

(4)Descriptive: or self-explanatory translation: it uses generic terms (not CBTs) to convey the meaning. It is appropriate in a wide variety of contexts where formal equivalence is considered insufficiently clear. In a text aimed at a specialized reader, it can be helpful to add the original SL term to avoid ambiguity.

\section{Larson's (1995) Translations Procedures}

Below, we will discuss the steps, or procedures, which the translator follows as if they were done in a given order. But it must be kept in mind that, in practice, there will be this moving back and forth. At times, even while he is working on the final draft, the translator will go back and re-read things he looked at in his preparation. He should, as a matter of fact, often refer back to these materials.

\section{Translation Strategies}

Strategies of translation involve the basic tasks of choosing the foreign text to be translated and developing a method to translate it. Both of these tasks are determined by various factors: cultural, economic, political. Yet the many different strategies that have emerged since antiquity can perhaps be divided into two large categories. A translation project may conform to values currently dominating the target-language culture, taking a conservative and openly assimilations approach to the foreign text, appropriating it to support domestic canons, publishing trends, political alignments. Alliteratively, a translation project may resist and aim to revise the dominant by drawing on the marginal, 


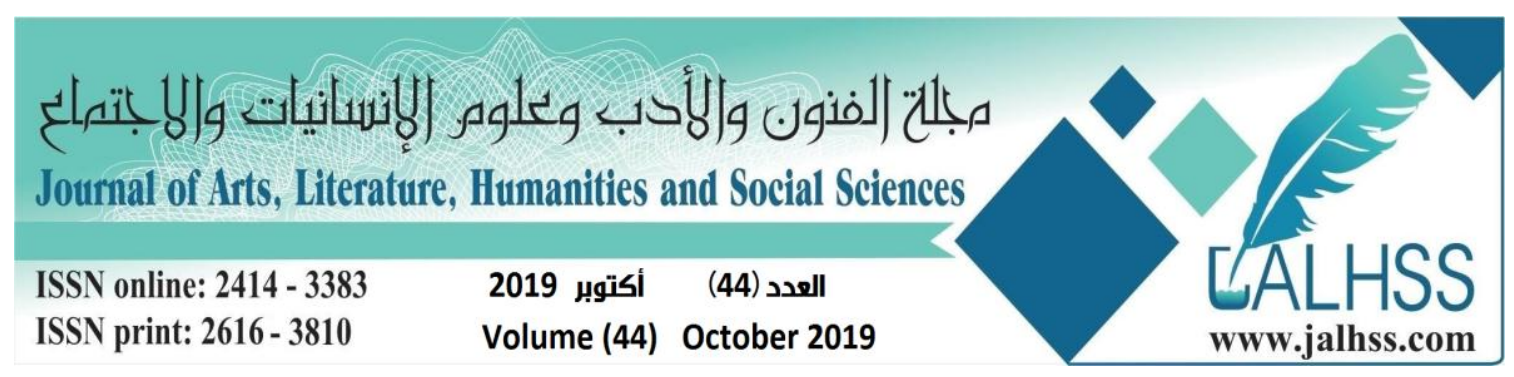

restoring foreign texts excluded by domestic canons, recovering residual values such as archaic texts and translation methods, and cultivating emergent ones (for example, new cultural forms). Strategies in producing translations inevitably emerge in response to domestic cultural situations. But some are deliberately domesticating in their handling of the foreign text, while others can be described as foreignizing, motivated by an impulse to preserve linguistic and cultural differences by deviating from prevailing domestic values.

Krings (1986) defines translation strategy as "translator's potentially conscious plans for solving concrete translation problems in the framework of a concrete translation task" and Seguinot (1986) believes that there are at least three global strategies employed by the translators: (1) translating without interruption for as long as possible (2) correcting surface errors immediately (3) leaving the monitoring for qualitative or stylistic errors in the text to the revision stage.

Moreover, Loescher (1991) defines translation strategy as "a potentially conscious procedure for solving a problem faced in translating a text, or any segment of it". As it is stated in this definition, the notion of consciousness is significant in distinguishing strategies which are used by the learners or translators. In this regard, he (1998) asserts that "the element of consciousness is what distinguishes strategies from these processes that are not strategic".

Furthermore, Bell (1998) differentiates between global (those dealing with whole texts) and local (those dealing with text segments) strategies and confirms that this distinction results from various kinds of translation problems.

Venuti (1991) indicates that translation strategies "involve the basic tasks of choosing the foreign text to be translated and developing a method to translate it". He employs the concepts of domesticating and foreign zing to refer to translation strategies.

Jaaskelainen (1999) considers strategy as, "a series of competencies, a set of steps or processes that favor the acquisition, storage, and/or utilization of information". He maintains that strategies are "heuristic and flexible in nature, and their adoption implies a decision influenced by amendments in the translator's objectives".

Taking into account the process and product of translation, Jaaskelainen (2005) divides strategies into two major categories: some strategies relate to what happens to texts, while other strategies relate to what happens in the process.

Product-related strategies, as Jaaskelainen (2005) writes, involves the basic tasks of choosing the SL text and developing a method to translate it. However, she maintains that process-related strategies "are a set of (loosely formulated) rules or principle which a translator uses to reach the goals determined by the translating situation" (p. 16). Moreover, Jaaskelainen (2005) divides this into two types, namely global strategies and local strategies: "global strategies refer to general principles and modes of action and local strategies 


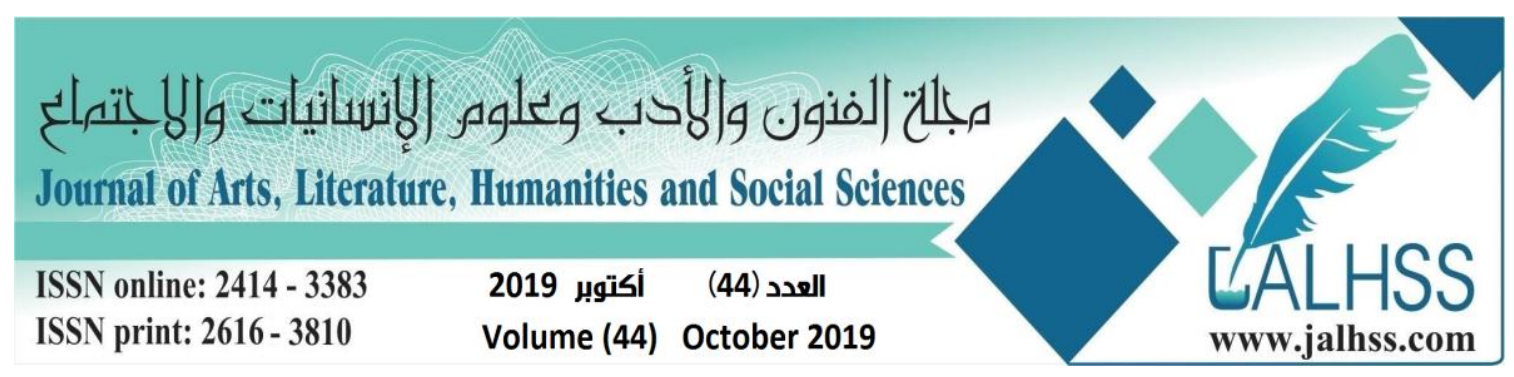

refer to specific activities in relation to the translator's problem solving and decision making.

\section{Leppihalme's Strategies}

Moreover, nine strategies for the translation of key-phrase allusions are proposed by Leppihalme (1997) as follows:

(1)Use of a standard translation,

(2)Minimum change, that is a literal translation, without regard to connotative or contextual meaning.

(3)Extra allusive guidance added in the text.

(4)The use of footnotes, translator's notes and other explicit explanation not supplied in the text but explicitly given as additional information.

(5)Stimulated familiarity or internal marking, that is the addition of intraallusive allusion.

(6)Replacement by a TL item.

(7)Reduction of the allusion to sense by rephrasing.

(8)Re-creation, using a fusion of techniques: creative construction of a passage which hints at the connotations of the allusion or other special effects created by it.

(9)Omission of the allusion.

\section{Our View of Techniques and Strategies of Translation}

Although some stylists consider translation "sprinkled with footnotes" undesirable their uses can assist the TT readers to make better judgment of the ST contents. In general, it seems that the procedures "functional equivalent" and "notes" would have a higher potential for conveying the concepts underlying the texts embedded in a text; moreover, it can be claimed that a combination of these strategies would result in a more accurate understanding of the texts than other procedures.

Various strategies opted for by translators in rendering allusions seem to play a crucial role in recognition and perception of connotations carried by them. If a novice translator renders a literary text without paying adequate attention to the allusions, the connotations are likely not to be transferred as a result of the translator's failure to acknowledge them. They will be entirely lost to the majority of the TL readers; consequently, the translation will be ineffective.

It seems necessary for an acceptable translation to produce the same (or at least similar) effects on the TT readers as those created by the original work on its readers. This paper may show that a translator does not appear to be successful in his challenging task of efficiently rendering texts when he sacrifices, or at least minimizes, the effect of allusions in favor of preserving graphical or lexical forms of source language texts. In other words, a competent translator is well-advised not to deprive the TL reader of enjoying, or even recognizing, the allusions either in the name of fidelity or brevity. 


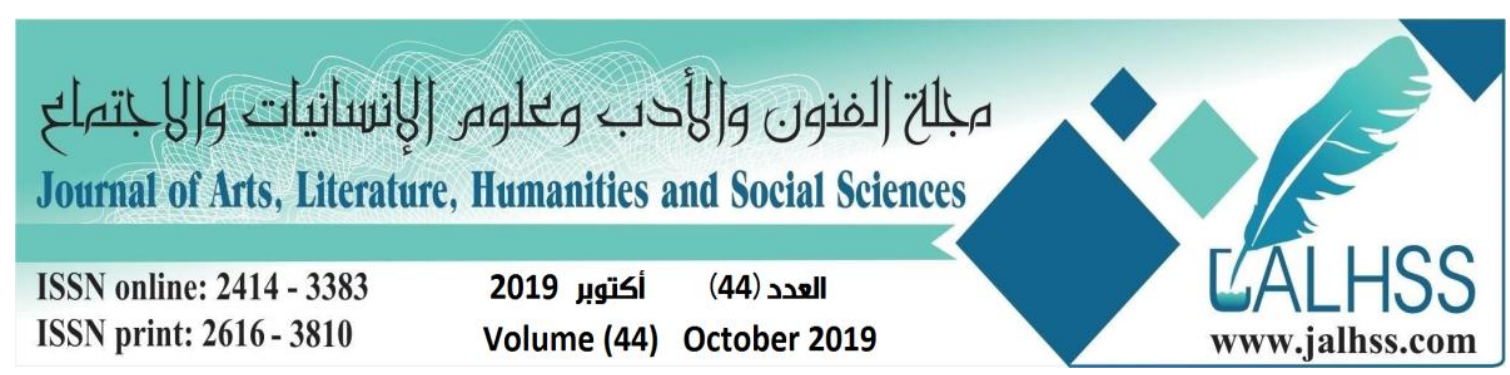

It can be claimed that the best translation method seem to be the one which allows translator to utilize "notes". Furthemore, employing "notes" in the translation, both as a translation strategy and a translation technique or procedure, seems to be indispensable so that the foreign language readership could benefit from the text as much as the ST readers do. All What have been mentioned cannot be achieved unless the translator is aware of both languages and both cultures. Hence, a contrastive study of both languages are needed and favorable. Consequently, grammar translation should be used in teaching English in departments of English, since a would-be translator must be bilingual and bi-cultural.

\section{The Importance of Translation in English language Teaching}

The following sections tackles the issue of how translation might best be used as a teaching technique in language classes. It initially presents a short historical review of the issue. Presenting some major justifications for taking translation as a teaching technique, the paper offers some practical guidance for incorporating the technique in the classrooms and methods of using bilingual texts

\section{The Significance of Translation in Teaching English Language}

By translation, we mean the transmission of a thought expressed in one language by means of another language. Translation is the interpretation of the meaning of a text in one language (the "source text") and the production, in another language, of an equivalent text (the "target text," or "translation") that communicates the same message (Catford,1965 and Chesteman 2013).

The significance of translation in foreign language teaching was of great importance. It was used as a means of conveying the meaning of a word, a phraseological group, a grammatical form or a sentence pattern. Translation was then considered to be a means of teaching a foreign language. But practice demonstrated, however, that the constant use of translation did not ensure the necessary conditions for students' direct comprehension and that speaking and reading were more important. Translation did not provide the development of speech habits and skills. Cosequently, the teacher might use translation when explaining new material and checking his students' knowledge (Cumpenasu,2002).

There were also several types of translation used in foreign language teaching. Taking into account the relationship between the mother tongue and the foreign language, there were three types of translation: translation from the foreign language into the mother tongue, translation from the mother tongue into the foreign language and retranslation (first students translated from the foreign language into the mother tongue and then, after a while, back into the foreign language). Then, if we considered translation from the point of view of its 


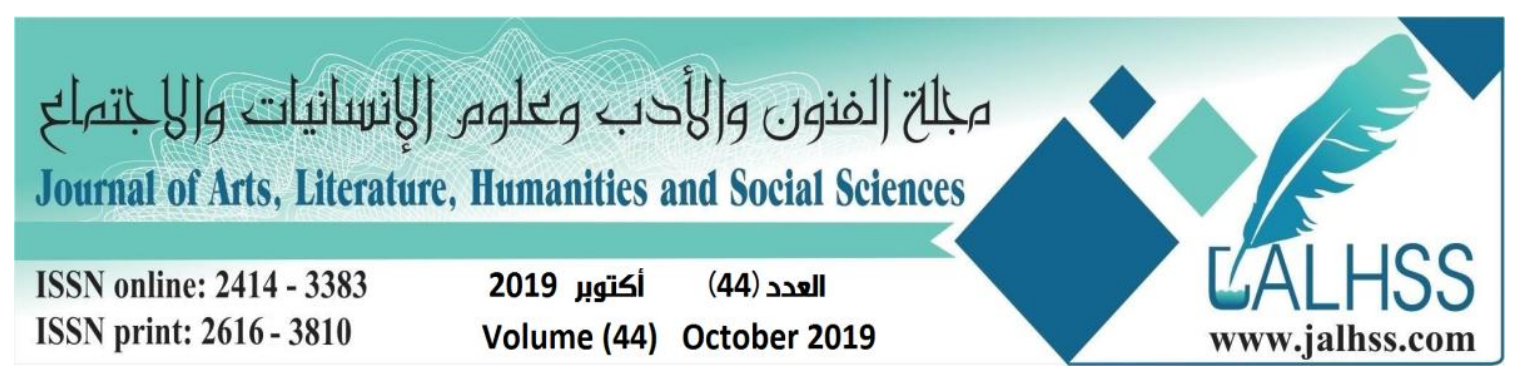

relation to the original, there were four types of translation: word for word translation (or literally translation) which drew a comparision between the elements of the target language and those of the mother tongue observing in this way, the difference between these languages (Gentzler, 1993, SnellHornby,2006, pym, 2010, and Jemielity ,2012).

Another type of translation was adequate translation, which transmitted the thought expressed in the foreign language by means of the corresponding equivalents of the mother tongue, then free translation or free interpretation of the text in the mother tongue that was read or heard in the foreign language (Goudec,2007).

The literary-artistic translation assumed a translation, which required special skills and knowledge. Therefore, it could not be introduced in school syllabus requirements. This type of translation under its two forms: written and oral, was to be used with the aim of checking students'comprehension and their knowledge of vocabulary and grammar.

Consequently, translation was considered a means of teaching of foreign language and its various types were also recommended (Brown 2001, Darian,2001, Bowker and Corpas Pastor,2016)

Translation must take into account a number of constraints, including context, the rules of grammar of the two languages, their writing conventions, their idioms, semantic elements, pragmatic elements, and stylistic elements.

Perhaps the most common misconception about translation is that there exists a simple "word-for-word" relation between any two languages, and that translation is therefore a straightforward and mechanical process. On the contrary, translation is always fraught with uncertainties and with the potential for inadvertent "spilling over" of idioms and usages from one language into the other (Nunnan,1999,As-Saafi 2008).

To decode the meaning of a text, the translator must first identify its component "translation units," that is to say, the segments of the text to be treated as a cognitive unit. A translation unit may be a word, a phrase or even one or more sentences. Behind this seemingly simple procedure lies a complex cognitive operation. To decode the complete meaning of the source text, the translator must consciously and methodically interpret and analyze all its features. This process requires thorough knowledge of the grammar, semantics, syntax, idioms, and the like, of the source language, as well as the culture of its speakers. 


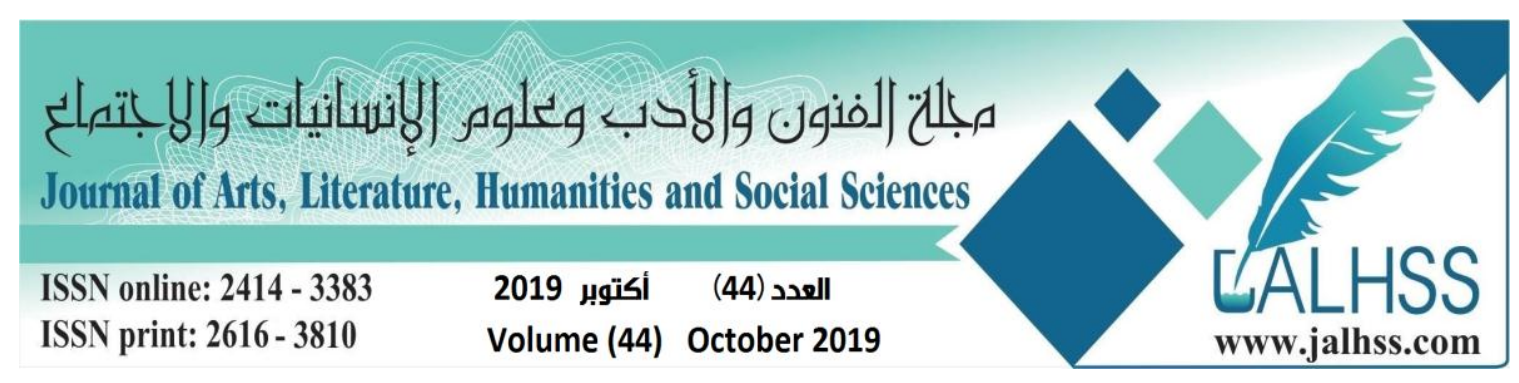

What have been said can be illustrated by the following diagram:

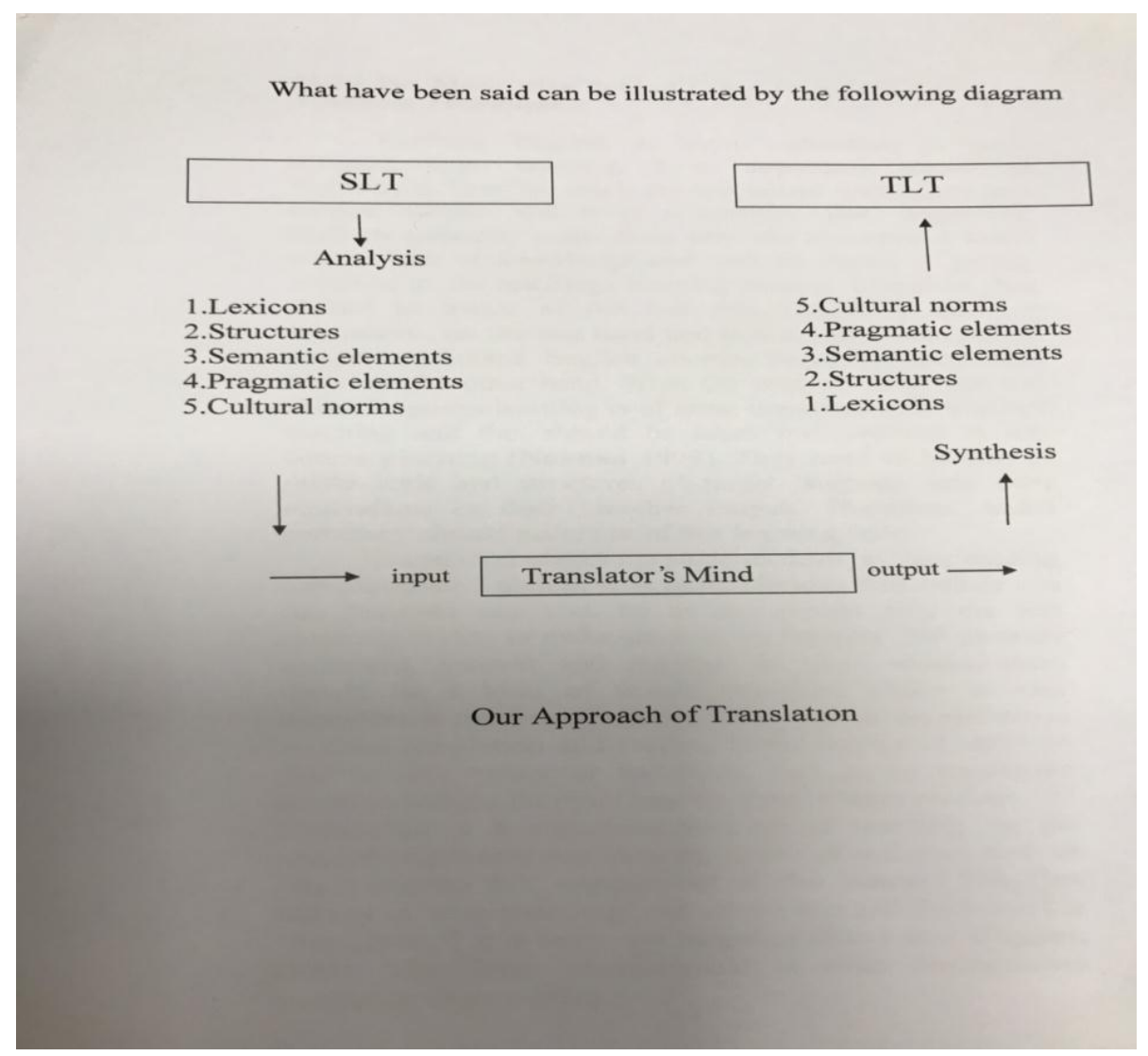

14 The Motivation Behind Using Translation as a Teaching Technique

Teaching English at higher education is quite different from teaching it at secondary school or high school. Here we teach the specialised vocabulary in a certain domain and it is a complex task. Moreover, students generally come from previous educational levels with a lack of knowledge and with no desire of getting involved in the teaching-learning process. Therefore, they should be aware of the fact that English is essential nowadays, on the one hand and that at this level they are taught specialised English courses based on specialised texts, on the other hand. What the students think and feel about language learning is of great importance in language teaching and this should be taken into account in any course planning (Nunnan 1999). They need to be able to relate lexis and structures of target language into their equivalents in their mother tongue. Therefore, sound pedagogy should make use of this learning style.

Translation makes the students develop their reading comprehension ability. It is quite obvious that before one can translate any text, he or she should read the text carefully, trying to make sense of its features like sentence structures, context and register. In other words, there should be a kind of textual analysis, 


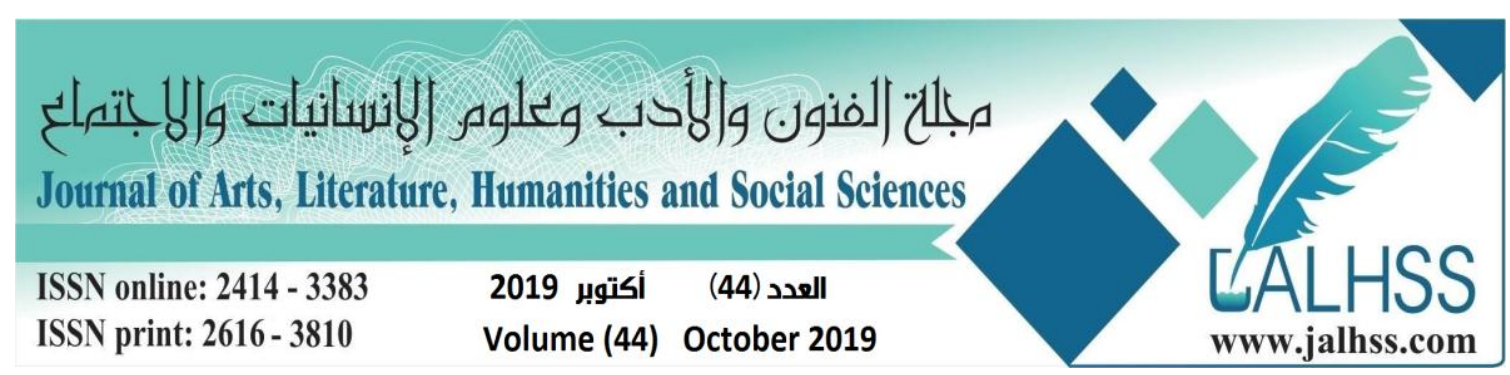

which is very important in reading comprehension. Indeed the difference between translation and reading is the degree of attention paid by the reader or translator, that is, in translation attention weighs far more heavily than in mere reading.

Translation is a conscious process of learning. In the translation process there are two types of activities both of which require full engagement of the learner. The first activity is "understanding" the source text and the second is "formulating" it in the target language (Hevy and Higgins, 1992). This latter characteristic is what distinguishes translation from reading.

Translation is a kind of communicative activity, which is practiced within a meaningful context (Duff 1990). It enhances interaction between the teacher and the students and among the students themselves due to the fact that rarely is there any absolute "right" rendering of the text (Stern, 1991).

Translation can be used as an evaluative technique in reading classes. As reading is totally unobservable, comprehension should be inferred from the other behavior; it is important to be able to accurately assess students comprehension of the text reading That is, among the other techniques like "doing," "transferring," "answering," "extending," and "modeling," we may ask students to translate part of the reading text into their native language to ensure if they have fully grasped the meaning. This can be done at the end of the reading lesson.

\section{The Concept of Grammar Translation Method}

The Grammar-Translation Method focuses on the teaching of the foreign language grammar through the presentation of rules together with some exceptions and lists of vocabulary translated into the mother tongue. Translation is considered to be the most important classroom activity. The main procedure of an ordinary lesson follows this plan: a presentation of a grammatical rule followed by a list of vocabulary and, finally, translation exercises from selected texts.

Other activities and procedures can be the following: answering comprehension questions on the text; students find antonyms and synonyms words in the text; vocabulary is selected from the reading texts and memorized; sentences are formed using new words; fill-in-the-blank exercises; writing compositions on the topic.

\section{Characteristics of Grammar Translation Method}

1. It uses mother tongue.

2. It is teacher-centred or biased.

3. The vocabulary taught through wordlists and translation.

4. Reading of literary passages even at low levels, with reading comprehension questions

5. Practice should be based on translation of texts from source language to target language.

6. It elaborates presentation of grammar rules. 


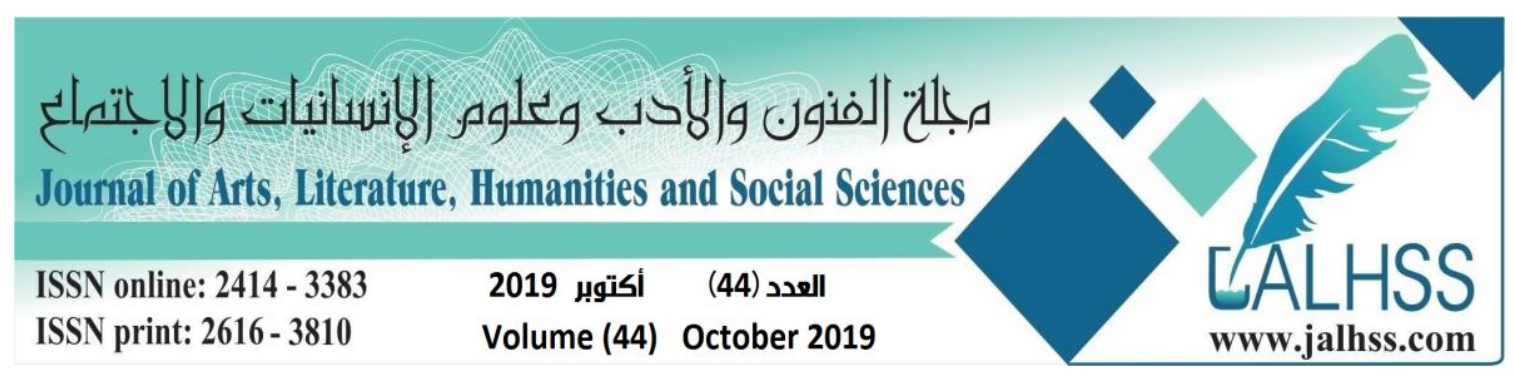

7. It depends on memorization of grammar rules and vocabulary.

8. Vocabulary exercises include antonyms and synonyms, definitions etc based on words in reading texts.

9. Composition exercises based on topics from reading texts.

\section{Principles of Grammar Translation Method}

The most relevant principles of this method can be summarized as follows:

1. It confirms the study and translation of the written language, as it is considered superior to spoken language.

2. Reading and writing are the main language skills.

3. The student's native language is the medium of instruction and used as well to compare with the language studied.

4. The structural patterns of two languages are compared and this comparison makes learning more clear and firm.

5. The fundamental principle of proceeding from known to unknown is followed throughout.

6. Successful learners are those who translate each language into the other, though they cannot communicate orally.

7. Students have to know verb conjugations and other grammatical paradigm

8. The knowledge of rules helps the learners to avoid any types of mistakes.

9. Teachers play an authoritarian role in the classroom and the predominant interaction is between teacher-student.

10. Vocabulary is learnt from bilingual word lists.

11. A Paramount use of translation exercises is given.

12. The procedure of teaching English is a combination of activities of teaching grammar and translation.

\section{Advantages of Grammar Translation Method.}

1. By telling the meaning of the word or sentence in mother tongue, the teacher can at once make the students understand Thus, he saves time and efforts.

2. The students are able to learn many items of English by comparison with mother tongue.

3. The comprehension of the students can be tested very easily.

4. Knowledge is acquired gradually, by traversing the facts of language and the syntactic mechanisms, going from simplest to the most complex.

5. Learning grammar, the students examine the texts developing awareness that language constitutes a system which can be analyzed.

6. This method is useful in the class in which there are a large number of students.

7. It is beneficial to use in the class where there are students of various levels very intelligent and not-so-very intelligent (individual differences).

8. The students understand the things very easily if taught using this method.

9. It doesn't consume the time in finishing the syllabus. 


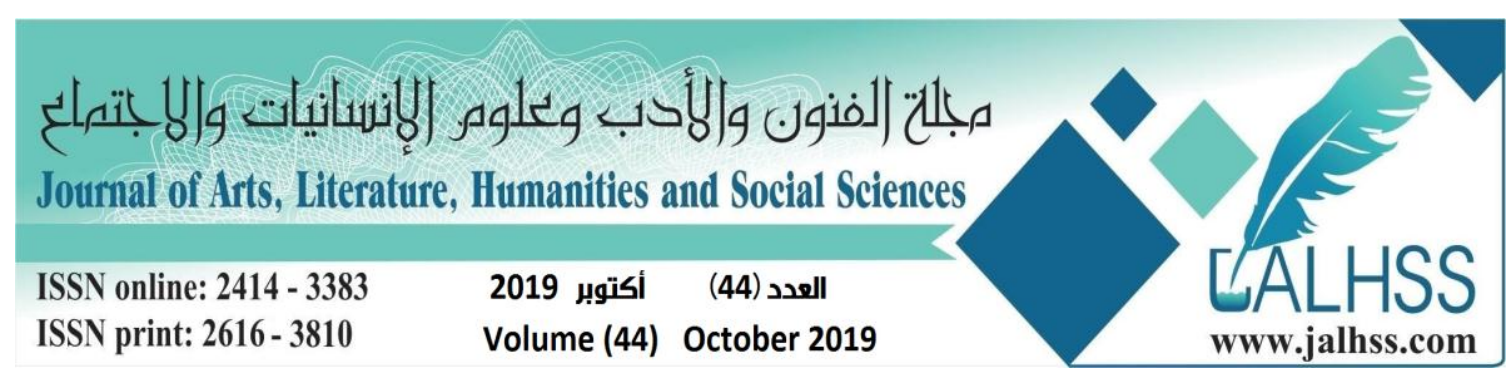

10. Precise pictures of things can easily be made in the minds of the learners using this method.

11. This Method is very useful for the average and below-average students.

\section{Methodology and its Application}

It is advisable that teachers of Department of English should follow our approach of teaching of translation subjects, since, it is very comprehensive and can have a clear description of the languages involved in the process of translation. Thus the teacher should

1. Read the text carefully and comprehensively.

2. Specify the Lexicons which need to be understood their meanings and grasped fully.

3. Know the syntactic structure of both source Language and Target Language.

4. Pick up all semantic elements in the text to find their equivalents in the Target Language, like collocational expressions, Idiomatic expressions, proverbs, etc.

5. Be aware of the pragmatic elements such as deixis, speech acts, implicatures, etc.

6. Know the stylistic features of the text in question so as to select their counterparts in the target text.

7. Specify all cultural norms in the text under translation so that he will be able to find their equivalents in order to create the target text.

8. All points that have been mentioned can be achieved through the process of "analysis" and "synthesis".

\section{Conclusions}

There are some good reasons for the purposeful inclusion of translation activity in our classrooms.

1.As a communicative activity, it enhances interaction between teacher and students and among the students themselves.

2.Being a conscious process of language learning, it fully engages the learners in the learning process.

3.Translation helps students develop their reading comprehension abilities.

4.It can be used as an evaluative technique for checking students reading comprehension of a particular text.

However, in order to obtain the above-mentioned benefits, we must consider some points.

1. The students should be initially given prior guidance on the practical procedures of translation activity and encouraged to work in groups to get the best translation.

2. The degree of students' L2 proficiency along with the degree of the text difficulty should also be considered. 


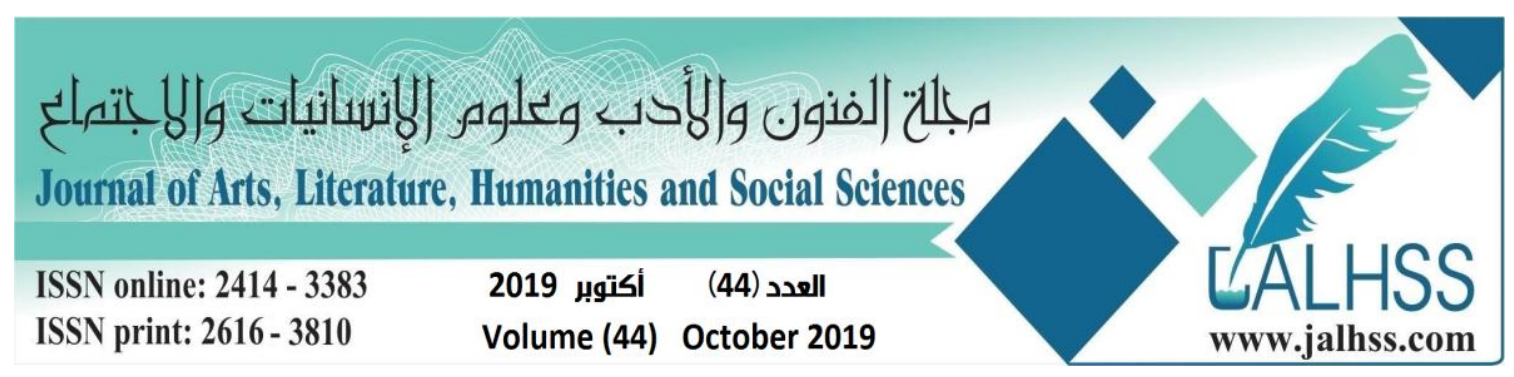

3. The students must be provided with full theoretical information about the grammatical structures of both languages (Source language and Target language).

4. The students should be familiarized with semantic elements, like synonymy, hyponymy, antonymy, collocational expressions, and idiomatic expressions.

5. The students must be familiarized with pragmatic elements such as intentionality, speech acts, ambiguity whether pragmatic ambiguity or any other type of ambiguity.

6. Familiarizing the students of translation with cultural norms is very important.

7. Teaching tradition is not a matter of replacing words with words or structures with structures. It is a matter of analysis of the whole elements of the source language and synthesis of all elements of target language.

\section{References}

1. As-Saafi , A.B.(2008): Translation Theories, Strategies and Basic Theoretical Issues , Petra: Petra university press.

2. Al-Sulaimaan,M.D.(2016): Translation: Theory and Practice, Erbil: Haval Art Printing Press.

3. Bassnett, S. (2002): Translation Studies. London: Routledge.

4. Bell, R.T. (1991): Translation and Translating: Theory and Practice, London: Longman Ltd.

5. Bernardini, S. (2016): Discovery Learning in the language for-Translation Classroom: Corpora as 36(1), 14-35. Learning Aids. Cadernos de Traducao, 36: (1), 14-35.

6. Bowker, L., \& Corpas Pastor, G. (2014): “Translation Technology". In R. Mitkov (ed.), The Oxford Handbook of Computational linguistics, Oxford: Oxford University press.

7. Brown, H. Douglas (2001): Teaching by Principles: An Interactive Approach to Language Pedagogy. Second Edition: NY: Longman.

8. Calder bank, T. (1990): Translation Strategies for an Arabic Political Argumentative (Unpublished MA Dissertation), University of Sanford.

9. Catford, J.C. (1965):A Linguistic Theory of Translation, Oxford: Oxford University press.

10. Chesterman, A. (2013): "Models of what processes"? Translation and Interpreting Studies, 8(2), 155-168.

11. Cumpenasu, Gisela Florentina (2007): “The Role of Translation in Foreign Language Teaching" - In BDD-A5589

12. Darian, S. (2001): "Adapting Materials for Language Teaching”. FORUM. Vol. 39.No: 2, p.2.

13. Duff, A. (1990): Translation, Oxford: Oxford University Press. 


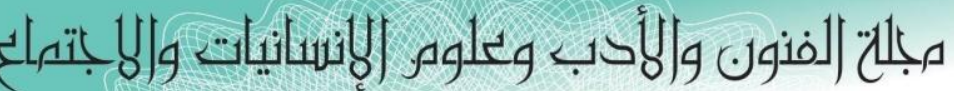

Journal of Arts, Literature, Humanities and Social Sciences

ISSN online: 2414 - 3383

ISSN print: 2616 - 3810

\section{العدد (44) أكتوبر 2019 \\ Volume (44) October 2019}

¿ALHSS

WWW.jalhss.com

14. Nunnan, D.(1999): Second Language Teaching and Learning, Boston: Heinle\& Heinle Publishers.

15. Hervey, S. and Higgins, I. (1992): Thinking Translation: A Course in Translation Method, London: Rutledge.

16. Gentzler, E. (1993): Contemporary Translation Theories, London:Routledge.

17. Goudec, D. (2007):Translation as a Profession, Amsterdam: John Benjamins.

18. Graedler, A.L (2000): Cultural Shock Retrieved 6/12/2006 http:// www.uio.no/iba/nettkurs/translation/grammar/top7 culture. html.

19. Harvey, M. (2003): A Beginner's Course in legal Translation London: Longman.

20. Jaakkelainen, R. (1999): Tapping the Process, Joensuu: University of Joinsuu press.

21. Jemielity, D. (2012): Managing Multilingual Communication Processes, Liechtenstein: BSL Banking.

22. Krings, H.P. (1986): Translation Problems and Translation Strategies, Tubingen: Gunternarr.

23. Leppihalme, R.(1997): Culture Bumps: An Empirical Approach to the Translation of Allusion, Clevedon: Multilingual.

24. Loescher, W. (1991): Translation Performance, Translation Process and Translation Strategies, Uebingen: Guten Natrr.

25. Newmark, P.(1981): Approaches to Translation, Oxford and New York: Pergamon.

26. Newmark, P.(1988): A Textbook of Translation, London : Prentice Hall.

27. Newmark, P.(1991): About Translation, Philadelphia: Multilingual Matters Ltd.

28. Nida, E.(1995): "Dynamic Equivalence in Translation". In: Chan, Sin-Wai and Pollard, D.E.(eds), pp.223 - 230.

29. Pym, A. (2010): Exploring Translation Theories. London: Routledge.

30. Sarcevic, S. (1997): New Approach to Legal Translation, The Hague: Kluwer Law International.

31. Seguinot, C. (1989): The Translation Process, Torento: It.G. Publication.

32. Snell-Hornby, M. (2006): The Turns of Translation Studies. Amsterdam: John Benjamins.

33. Stern, H. H. (1991): Fundamental Concepts of Language Teaching, Oxford: Oxford University Press.

34. Wettstein, H. (1991): Has Semantics Rested on a Mistake? Standford: Standford University Press. 